\title{
IMPACT OF CORPORATE SOCIAL Responsibility PeRformance on The Value of Cash Holdings
}

\author{
Hoontaek Seo and Daniel L. Tompkins
}

Hoontaek Seo, Associate Professor of Finance, Niagara University, email: hseo@niagara.edu

Daniel L. Tompkins, Professor of Finance, Niagara University, email: dlt@niagara.edu

\begin{abstract}
Using a sample of U.S. firms from 1991 to 2013, we examine the impact of corporate social responsibility (CSR) performance on corporate cash holdings and the value of cash holdings. We find that firms with high CSR rating tend to hold more cash than those with low CSR rating. We also find that the market value of excess cash reserves is higher for firms with high CSR rating. Finally, we find that excess cash investment by firms with low CSR rating results in lower operating performance. However, this negative effect of excess cash investment on operating performance is cancelled out if the firm has high CSR rating. Overall, our results indicate that CSR activities can improve firm value and support the conflict resolution view of CSR.
\end{abstract}


Keywords: CSR, cash holdings

DOI: http://dx.doi.org/10.15239/j.brcacadjb.2019.09.01.ja02

\section{INTRODUCTION}

Despite Milton Friedman's (1970) essay that increasing profits is business' social responsibility, many U.S. firms increased their investment in Corporate Social Responsibility (hereafter CSR) activities and published annual CSR reports. Even though awareness and interest in CSR has been on the rise, debate exists about the CSR's role in the firm. The debate centers on whether CSR activities increase agency cost through management entrenchment or benefits shareholders through conflict resolution.

The managerial entrenchment view of CSR argues that mangers engage in activities in order to become hard to fire and extract private benefits (Tirole, 2001). According to this view, CSR activities are a means for managers to increase their private benefits. (Deng, Kang and Low, 2013, Arouri and Pijourlet, 2015).

Alternatively, conflict resolution view of CSR argues that CSR activities benefit a firm. Kitzmiller and Shimshak (2012) provide evidence that CSR activity provides utility to owners through the "warm glow" from being a part owner of a socially responsible firm. Even Friedman in his essay states that CSR may increase firm value through attracting good employees, etc.

An extensive literature examines the effect of CSR on corporate financial performance. For example, Servaes and Tamayo (2013) show that CSR and firm value are positively related for firms with high customer awareness. Deng, Kang and Low (2013) show that merger announcement returns are positively associated with CSR. Using a worldwide sample, Arouri and Pijourlet (2015) provide evidence that CSR performance has a positive effect on the value of cash holdings. 
Using a large sample of U.S. firms from 1991 to 2013, we investigate whether CSR performance has an impact on the value of cash holdings to distinguish between the conflict resolution view and the managerial entrenchment view. We find evidence that the market value of excess cash reserves is higher for a socially responsible U.S. firm. Our result is consistent with the conflict resolution view of CSR, i.e., that CSR activities are a means for managers to act in the shareholders' interests by resolving conflicts with a firm's stakeholders.

Our paper contributes to the literature by extending the work by Arouri and Pijourlet (2015). Using a worldwide sample, they show that investors assign a higher value to cash held by high CSR firms. Our study also extends the literature that investigates the effect of CSR on corporate financial performance by providing evidence that CSR performance can add value to a firm.

We organize the remainder of this paper as follows. First, we examine the existing literature underlying the conflict resolution and managerial entrenchment views. Following the literature review, we describe the data and sample. Next, empircal results are presented. The paper concludes with a summary of results and directions for future research.

\section{Literature Review AND Research Question}

This paper examines the relationship between corporate social responsibility performance and the value of cash on firm value. Two opposing views on CSR, the conflict resolution view as opposed to the managerial entrenchment view exist in the literature.

The conflict resolution view of CSR posits that engaging in CSR activities has positive effects of firms. The mechanism for these positive effects is through the resolution of conflicts with other stakeholders within the firm. By reducing the costs of free-riding or hold-up problems, Jones (1995) explains that "mutual trust and cooperation" among stakeholders works better than other means of trying to reduce the "opportunism" of 


\section{The BRC Academy Journal of Business Vol. 9, No. 1}

management. Arouri and Pijourlet, (2015) explain that high CSR ratings signals a good reputation and that the firm is a "desirable partner." Deng, Kang and Low, (2013) discuss that firms with high CSR activities show a stronger commitment to honoring implicit contracts. Thus, CSR activities may maximize shareholder wealth by enhancing the commitment of other shareholders. Further, Servaes and Tamayo (2013) show that CSR and firm value are positively related for firms with high customer awareness. Cheung (2016) finds that CSR investments lowers systematic risks which leads to use of shorter maturity debt for which the maturity risk is mitigated by increased cash holdings. These findings suggest that firms engaged in CSR have the ability to hold more cash. Also, the value of cash holdings increases with CSR activities according to Arouri and Pijourlet (2015)

Alternatively, others argue the managerial entrenchment view that through CSR activities managers get private benefits at the expense of shareholders by engaging in CSR activities. Surroca and Tribo (2008) argue spending cash flows on CSR investments also aligns labor and other stakeholders with managers against shareholders. Less powerful CEOs use CSR investments to become more powerful and entrenched according to Jiraporn and Chintrakarn (2013). Jensen (1986) argues that the agency relationship gives executives incentives to grow the firm beyond its optimum and will do so through misuse of free cash flows. This suggests that CSR activities are associated with an inefficient use of a firm's cash resources. If the managerial entrench view of CSR is correct, investors may discount the value of cash held by high CSR firms.

\section{Data Description}

In this section, we review the sample construction, measure of corporate social responsibility performance, and descriptive statistics. 


\section{Sample Construction}

The sample includes all US publicly traded firms reported by Kinder, Lyndenberg and Domini (KLD) database between 1991 to 2013. Consistent with the previous literature, we exclude firms in financial (SIC 6000-6999) or utilities (SIC 4900-4999) industries. Following Faulkender and Wang (2006), we eliminate firm-years with negative net assets, negative market value of equity, or negative dividends. Our final sample consists of 27,096 firm-year observations.

\section{Measure of Corporate Social Responsibility Performance}

We measure a firm's corporate social responsibility (CSR) performance based on the KLD database, which has been widely used in the CSR literature. KLD evaluates firms' CSR performance annually in seven qualitative areas: community, diversity, corporate governance, employee relations, environment, human rights, and product characteristics. Within each of these areas, there are a set of indicators for each strength and concern activity. A firm gets one if it meets the criteria for an indicator, otherwise it gets zero. The score of each area is the number of strengths minus the number of concerns. A firm's CSR score is the sum of seven area scores, with a higher value indicating a high CSR performance.

\section{Descriptive Statistics}

All variables in dollars are inflation-adjusted to 2013 dollars using the consumer price index (CPI). All continuous variables (except the CSR variable) are winsorized at the 1st and 99th percentiles in order to minimize the impact of outliers. Table 1 provides summary statistics for the key variables in this study. Firms hold $50 \%$ of sales in cash on average. This indicates that the sample firms hold a substantial portion of their value in cash. The sample firms show an average CSR score of -0.27 . The average firm in our sample has net assets of $\$ 4.98$ billion.

Table 2 reports Pearson correlation coefficients among the key variables in this study. Cash holdings is positively and significantly related to CSR. 


\section{The BRC Academy Journal of Business Vol. 9, No. 1}

\section{EMPIRICAL RESULTS}

In this section we discuss measuring excess cash, the value impact of CSR performance on cash holdings, and the impact of CSR performance on the use of excess cash.

\section{PREVIEW COMPLETE}

This completes the limited preview of this paper. Please visit the link below to purchase.

\section{Citation Information}

Seo, Hoontaek and Daniel L. Tompkins. "Impact of Corporate Social Responsibility Performance on the Value of Cash Holdings." The BRC Academy Journal of Business 9, no. 1 (2019): 33-44. http:// dx.doi.org/10.15239/j.brcacadjb.2019.09.01.ja02 